\title{
Cytokines in chronic obstructive pulmonary disease
}

\author{
K.F. Chung
}

\begin{abstract}
Cytokines in chronic obstructive pulmonary disease. K.F. Chung. (C) ERS Journals Ltd 2001.

ABSTRACT: Chronic obstructive pulmonary disease (COPD) is characterized by chronic obstruction of expiratory flow affecting peripheral airways, associated with chronic bronchitis (mucus hypersecretion with goblet cell and submucosal gland hyperplasia) and emphysema (destruction of airway parenchyma), together with fibrosis and tissue damage, and inflammation of the small airways. Cytokines are extracellular signalling proteins. Increased levels of interleukin (IL)-6, IL-1 $\beta$, tumour necrosis factor- $\alpha$ (TNF- $\alpha$ ) and IL-8 have been measured in sputum, with further increases during exacerbations, and the bronchiolar epithelium over-expresses monocyte chemotactic protein (MCP)-1 and IL-8. IL-8 can account for some chemotactic activity of sputum, and sputum IL-8 levels correlate with airway bacterial load and blood myeloperoxidase levels. The expression of chemokines such as regulated on activation, normal T-cell expressed and secreted (RANTES) may underlie the airway eosinophilia observed in some COPD patients. Cytokines may be involved in tissue remodelling. TNF- $\alpha$ and IL-1 $\beta$ stimulate macrophages to produced matrix metalloproteinase-9 (MMP-9), and bronchial epithelial cells to produce extracellular matrix glycoproteins such as tenascin. Increased expression of transforming growth factor- $\beta$ (TGF $\beta$ ) and of epidermal growth factor (EGF) occurs in the epithelium and submucosal cells of patients with chronic bronchitis. TGF $\beta$ and EGF activate proliferation of fibroblasts, while activation of the EGF receptor leads to mucin gene expression.

The cytokine profile seen in chronic obstructive pulmonary disease is different from that observed in asthma. The role of these cytokines needs to be defined and there is a potential for anticytokine therapy in chronic obstructive pulmonary disease.

Eur Respir J 2001; 18: Suppl. 34, 50s-59s.
\end{abstract}

Correspondence: K.F. Chung

National Heart \& Lung Institute

Imperial College School of Medicine

Dovehouse Street

London SW3 6LY

UK

Fax: 442073518126

Keywords: Chronic obstructive

pulmonary disease

cytokines

epidermal growth factor

interleukin-1 $\beta$

interleukin-8

transforming growth factor- $\beta$

tumour necrosis factor- $\alpha$

Received: March 262001

Accepted May 142001
Cytokines are extracellular signalling proteins, usually of $<80 \mathrm{kDa}$ in mass and produced by different cell types involved in cell-to-cell interactions. They affect closely adjacent cells, and therefore function in a predominantly paracrine fashion. They may also act at a distance (endocrine) and have effects on the cell of origin (autocrine). Cytokines are rarely produced individually; rather, they are produced along with other cytokines in patterns characteristic of particular diseases. There is wide pleiotropy and an element of redundancy in the cytokine family in that each cytokine has many overlapping functions, with each function potentially mediated by more than one cytokine. However, the effects of an individual cytokine may be influenced by other cytokines released simultaneously from the same cell or from target cells following activation by the cytokine, inducing either synergistic or antagonistic effects. The effects of cytokines are mediated by their binding to high-affinity cell surface receptors, usually present in low numbers and which can be upregulated on cell activation. The receptors for many cytokines have been grouped into superfamilies based on the presence of homologous regions. Cytokines themselves may induce the expression of receptors that may in turn change the responsiveness of both source and target cell. Some cytokines may stimulate their own production in an autocrine manner, whereas others stimulate the synthesis of different cytokines that have a feedback stimulatory effect on the first cytokine resulting in an increase in its effects. The potential contributions of cytokines to disease have been explored in studies using cytokines as agonists, by blocking the effects of specific cytokines, via the overexpression and deletion of cytokines in transgenic mice, and in genetic studies.

Since the pathology of chronic obstructive pulmonary disease (COPD) is that of a chronic inflammatory process with tissue damage and repair processes, it is not surprising that many cytokines play a role in this condition. This review highlights apparently important cytokines, and their effects. One of the main focuses of research on cytokines is the determination of ways in which the effects of these cytokines or their production may be inhibited, but this is not reviewed here.

\section{Classification of cytokines}

Classification of cytokines with respect to airways disease is best considered functionally, with categories such as proinflammatory cytokines, T-cell-derived cytokines, chemoattractant cytokines (chemokines) 
for eosinophils, neutrophils, monocytes/macrophages and T-cells, anti-inflammatory cytokines, and growth factors (table 1).

\section{Lymphokines}

Originally, lymphokines, which are soluble factors, generated by activated lymphocytes, particularly CD4+ T-cells, in response to specific or polyclonal antigens were described, and formed the most important class of cytokines involved in immunological mechanisms. Particular subsets of CD4+ T-cells may be induced preferentially, secreting defined patterns of cytokines, resulting in the initiation and propagation of distinct immune effector mechanisms. Studies in mouse CD4+ T-cell clones, and later in human CD4+ T-cells, have revealed two polarized basic functional subsets termed T-helper (Th) type 1 and Th2. Th1 are characterized by predominant secretion of interleukin (IL)-2, interferon (IFN) and tumour necrosis factor (TNF), triggering both cellmediated immunity and production of opsonizing antibodies, whereas Th2 secrete predominantly IL-4, -5, -10 and -13 , responsible for immunoglobulin (Ig) $\mathrm{E}$ and $\mathrm{IgG} 4$ production, and activation of mast cells and eosinophils [1]. A third Th subset, Th0, shows a composite profile, producing both Th1 and Th2-associated cytokines. In asthma, there is a predominance of expression of Th2-derived cytokines such as IL-4, -5 and -13 [2, 3], leading to the hypothesis that asthma may result from an imbalance of Th2derived cytokines.

Table 1.-Cytokines in chronic obstructive pulmonary disease

\begin{tabular}{|c|c|}
\hline Category & Cytokines \\
\hline Lymphokines & IL-4, IL-5, IL-6, IL-10, IL-13 \\
\hline \multirow{2}{*}{$\begin{array}{l}\text { Chemotactic factors for } \\
\text { Neutrophils }\end{array}$} & \\
\hline & $\begin{array}{l}\text { CXC chemokines (IL-8, } \\
\text { GRO- } \alpha, \text { ENA-78), IL-1, } \\
\text { TNF, IL-17 }\end{array}$ \\
\hline Eosinophils & $\begin{array}{l}\text { CC chemokines (eotaxin, } \\
\text { RANTES, MCP-4), } \\
\text { GM-CSF }\end{array}$ \\
\hline $\begin{array}{l}\text { Monocytes/ } \\
\text { macrophages }\end{array}$ & MCP-1, MIP-1 $\alpha$, RANTES \\
\hline T-cells & $\begin{array}{l}\text { IL-16 (CD4+), MIP-1 } \alpha \text { (CD8+), } \\
\text { STCP-1 (Th2), RANTES } \\
\text { (memory), MCP-1 }\end{array}$ \\
\hline Proinflammatory & IL-1 $\beta$, TNF- $\alpha$, IL-6 \\
\hline Anti-inflammatory & IL-10, IL-1RA, IFN- $\gamma$ \\
\hline Growth factors & TGF- $\beta$, PDGF, EGF, IGF \\
\hline
\end{tabular}

IL: interleukin; GRO- $\alpha$ : growth-related oncogene- $\alpha$; ENA-78: epithelial-derived neutrophil activator 78; TNF: tumour necrosis factor; RANTES: regulated on activation, normal T-cell expressed and secreted; MCP: monocyte chemotactic protein; GM-CSF: granulocyte-macrophage colony-stimulating factor; MIP-1 $\alpha$ : macrophage inflammatory protein $1 \alpha$; STCP-1: stimulated T-cell chemoattractant protein-1; Th2: type 2 Thelper cell; IL-1RA: IL-1 receptor antagonist; IFN- $\gamma$ : interferon gamma; TGF- $\beta$ : transforming growth factor- $\beta$; PDGF: platelet-derived growth factor; EGF: epidermal growth factor; IGF: insulin-like growth factor.
Like CD4+ T-cells, CD8+ T-cells show dichotomy of expression of lymphokines. Most CD8+ T-cells were thought to exhibit a Th1-cytokine profile alone and to rarely produce IL-4. However, under certain conditions, CD8+ T-cells can produce IL-4 [4, 5]. CD8+ T-cells can differentiate into cells that make IFN- $\gamma$ but not IL-4 (cytotoxic T-cell (TC) type 1), and cells that make IL-4 but not IFN- $\gamma($ Tc2) $[6,7]$. CD8+ $\mathrm{T}$-cell biology is of particular interest in COPD since increased expression of CD8+ T-cells occurs in the airways of patients with COPD [8]. CD8+ T-cells have cytotoxic properties, and can mediate inflammatory changes [9]. Overall, Tc2 CD8+ T-cells may contribute to airway inflammation in models of allergic inflammation. For example, in mice exhibiting a strong Th2 response, a CD8+ T-cell response to viral infections led to an increase in virus-specific CD8+ T-cells that make IL-5, which caused lung eosinophilia [10]. These lymphokines can also be expressed by cells other than T-cells, such as macrophages, epithelial cells and mast cells, and may take part in more general inflammatory processes.

\section{Chemokines}

Other classes of cytokine include chemokines, which have important chemoattractant properties, and growth factors, which mediate the proliferation, differentiation and survival of cells. Chemokines are chemotactic cytokines of $8-10 \mathrm{kDa}$ involved in attracting leukocytes into tissues. Since the first chemokine, IL-8, was described in 1987 [11, 12], >50 other chemokines have been recognized, encompassing four different structural families and interacting with $\geq 17$ different receptors [13]. The chemokine families, named according to the structure of conserved cysteine-containing motifs, are defined by the presence of $\mathrm{C}, \mathrm{CC}, \mathrm{CXC}$ or $\mathrm{C}^{\prime} \mathrm{C}$ motif at the amino terminus of the protein. The major families are $\mathrm{CC}$ chemokines ( $\beta$-chemokines), in which two cysteine $(\mathrm{C})$ residues are adjacent to each other, and CXC chemokines ( $\alpha$-chemokines), in which these residues are separated by a nonconserved amino acid (X). The $\mathrm{CC}$ chemokines are involved in chemoattraction of eosinophils, monocytes and T-lymphocytes and therefore of greatest relevance to asthma. The discovery of lymphotactin [14], a chemoattractant for lymphocytes, led to the description of another family, C chemokines. Lymphotactin lacks the first and third cysteines in the four-cysteine motif, but shares much similarity in amino acid sequence with the $\mathrm{CC}$ family of chemokines. Since the inflammatory pathology of asthma involves neutrophils, macrophages, T-cells and occasionally eosinophils, chemokines that are involved in the chemoattraction of these cells are of interest. Of the CXC chemokines, IL-8, growthrelated oncogene- $\alpha$ (GRO- $\alpha)$ and epithelial-derived neutrophil activator (ENA-78) are of particular interest with their chemoattractant and activating effects on neutrophils; these chemokines mediate their effects through a transmembrane domain-containing seven G-protein-coupled receptor, type 2 CXC receptor (CXCR) 2, whereas IL-8 activates CXCR1. Of the larger family of $\mathrm{CC}$ chemokines, regulated on 
activation, normal T-cell expressed and secreted (RANTES), macrophage inflammatory protein $1 \alpha$, monocyte chemotactic protein (MCP) 1, -3 and -4, and eotaxin may also be involved. Eotaxin acting through the type $3 \mathrm{CC}$ receptor (CCR) 3 is a selective chemoattractant for eosinophils, whereas RANTES exhibits a range of effects on memory $\mathrm{T}$ cell-, basophils and eosinophils, acting through CCR1, 3 and 5. MCP-3 and -4 may recruit eosinophils and mononuclear cells, whereas MCP-1 can recruit monocytes, lymphocytes and basophils, and can activate mast cells and basophils.

\section{Proinflammatory cytokines}

In this group, the cytokines IL-1, tumour necrosis factor (TNF), IL-6, granulocyte-macrophage colonystimulating factor (GM-CSF) and granulocyte colony-stimulating factor (G-CSF) may be included. IL-1 can be produced by a variety of cells, including monocytes/macrophages, fibroblasts, T-cells, neutrophils and airway epithelial cells, although the major source is the monocyte/macrophage. IL-1, like TNF and IL-6, is an endogenous pyrogen. It contributes to leukocytosis by release of neutrophils from bone marrow and induces the production of other cytokines, including IL-6, IL-8, RANTES, GM-CSF and $\mathrm{TNF}$, from a variety of cells. It induces expression of the adhesion molecules, intercellular adhesion molecule-1 (ICAM-1) and vascular cell adhesion molecule-1, on endothelial cells, which may lead to increased adhesion of neutrophils and eosinophils to the vascular endothelium and respiratory epithelium. Many of the effects of IL-1 $\beta$ are similar to those of $\mathrm{TNF}-\alpha$, which can stimulate airway epithelial cells to produce cytokines, including RANTES, IL-8 and GM-CSF. Both TNF- $\alpha$ and IL- $1 \beta$ induces fibroblasts to proliferate, and IL-1 $\beta$ increased synthesis of fibronectin and collagen.

G-CSF is involved in the maintenance of normal circulating granulocyte counts and of the neutrophilic response during infections. Together with IL-8, G-CSF increases the circulating neutrophil counts by accelerating proliferation of neutrophil maturation and release of mature cells into the circulation [15]. G-CSF also modulates neutrophil function, for example by increasing chemotactic mobility and CD11b/CD18 expression, enhancing cell adhesion to the endothelium, and increasing phagocytosis and inducing respiratory burst, together with neutrophil elastase $[16,17]$. A functional G-CSF receptor is required for normal chemoattractant-induced neutrophil activation [18]. GM-CSF is involved in priming inflammatory cells such as neutrophils and eosinophils, and can prolong the survival of eosinophils in culture [19]. GM-CSF induces the synthesis and release of a number of cytokines such as IL-1 and TNF- $\alpha$ from monocytes.

\section{Growth factors}

Growth factors such as platelet-derived growth factor (PDGF), transforming growth factor- $\beta$ (TGF- $\beta$ ), and epidermal growth factor (EGF) influence the proliferation of many structural cells, such as fibroblasts and airway smooth muscle cells, and the turnover of matrix proteins. They may be involved in airway repair and remodelling processes.

\section{Inflammation and cytokines in chronic obstructive pulmonary disease}

\section{Inflammation in chronic obstructive pulmonary disease}

COPD is characterized by chronic obstruction of expiratory flow affecting peripheral airways, often associated with chronic bronchitis (mucus hypersecretion with goblet cell and submucosal gland hyperplasia) and emphysema (destruction of airway parenchyma). Tissue damage with airway wall remodelling and thickening, inflammation and fibrosis of the small airways appear to play an important role in patients with COPD. The accompanying emphysema leads to loss of lung elastic recoil, contributing to decreased expiratory flow. Increased numbers of neutrophils and macrophages are usually recovered in bronchoalveolar lavage fluid and induced sputum from such patients, and in the small airways, there is a mucosal increase in the numbers of inflammatory cells, including of subepithelial CD68+ macrophages and $\mathrm{CD} 8+\mathrm{T}$-cells, but without prominence of neutrophils [20]. Some patients with COPD have a preponderance of eosinophils in their sputum, which may indicate significant improvement in forced expiratory volume in one second (FEV1) with corticosteroid therapy [21].

Neutrophils are more prominent in COPD than in asthma. Neutrophils have been implicated in causing tissue damage in COPD through the release of a number of mediators, including proteases such as neutrophil elastases and matrix metalloproteinases (MMPs), oxidants and toxic peptides such as defensins. A primary role for macrophages is also proposed because of their capacity to produce several metalloproteinases, including MMPs such as MMP-1, -9 and -12 [22]. Expression and production of MMP-1 and MMP-9 messenger ribonucleic acid (mRNA) is enhanced in macrophages from patients with COPD [23]. Inhaled cigarette smoke may induce alveolar macrophages to produce macrophage metalloelastase (MMP-12), which, in turn, induces chemotactic fragments that attract blood monocytes to the lung parenchyma. The role of the CD8+ T-cell remains unclear, but they produce granzymes and perforin, which can contribute to cell damage. One possibility is that these cells may be induced by certain virus infections, and virus-specific CD8+ T-cells may produce IL-5 [10].

\section{Cytokine profile in chronic obstructive pulmonary disease}

Increased levels of IL-6, IL-1 $\beta$, TNF- $\alpha$ and IL- 8 have been observed in induced sputum from patients with stable COPD (fig. 1) [24]. Increased release of the 


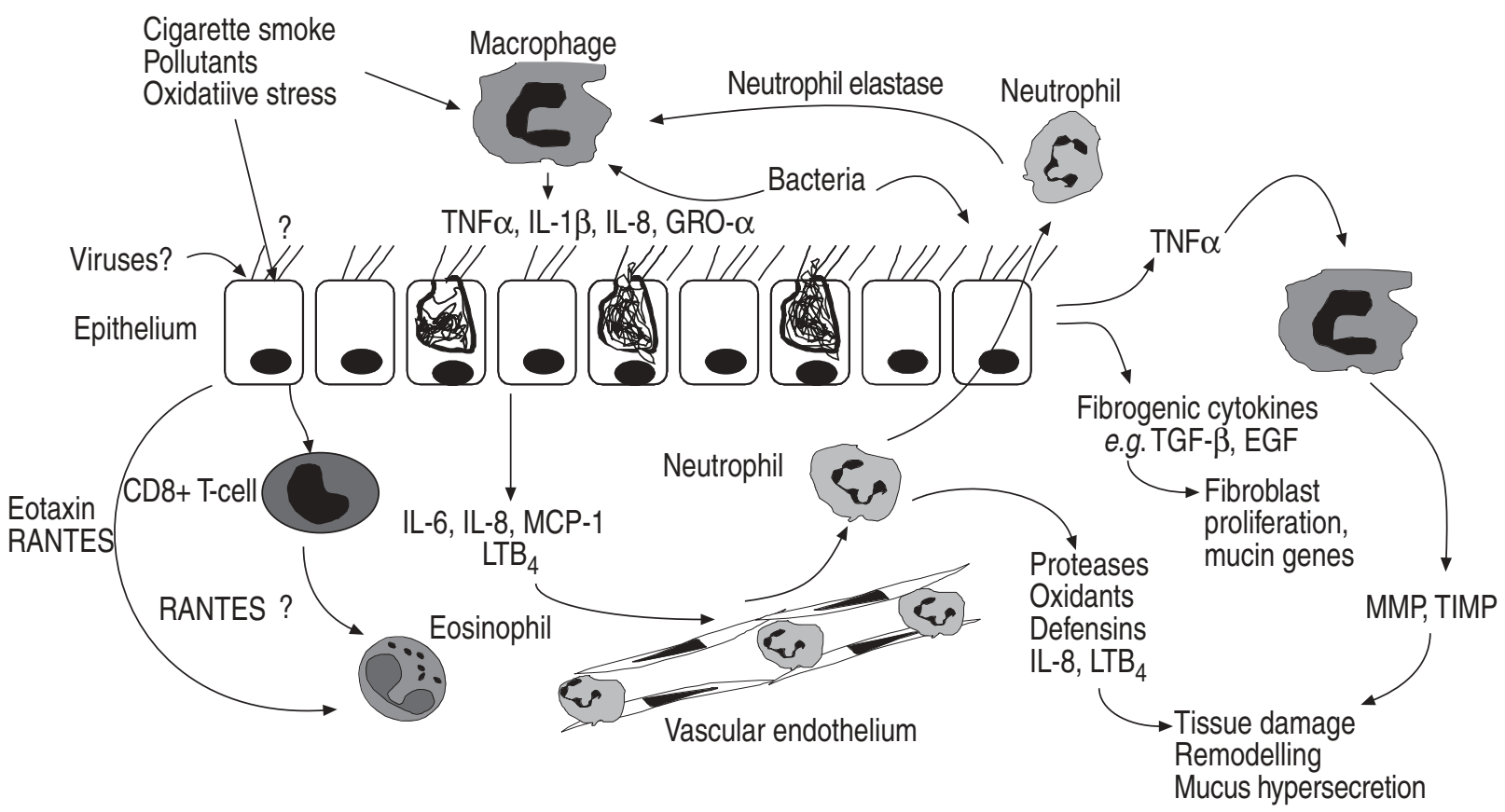

Fig. 1. - Interaction of cells and cytokines in the airway inflammation of chronic obstructive pulmonary disease.

The initiating factors include cigarette smoke interacting with macrophages and airway epithelium, inducing the release of chemotactic factors for neutrophils, which in turn are important effector cells for inflammation and tissue damage and repair. TNF- $\alpha$ : tumour necrosis factor- $\alpha$; IL: interleukin; GRO- $\alpha$ : growth-related oncogene- $\alpha$; TGF- $\beta$; EGF: epidermal growth factor; RANTES: regulated on activation, normal T-cell expressed and secreted; MCP-1: monocyte chemotactic protein-1; $\mathrm{LTB}_{4}$ : leukotriene $\mathrm{B}_{4}$; MMP: matrix metalloproteinase; TIMP: tissue inhibitor of matrix metalloproteinase.

proinflammatory cytokines, IL-8, IL-1 and TNF- $\alpha$, and of the anti-inflammatory cytokine, IL-10, from the alveolar macrophages of cigarette smokers and COPD patients has been observed [25]. Levels of TNF- $\alpha$, IL-1 $\beta$, IL-6, IL-8 and MCP-1 were increased in bronchoalveolar lavage fluid from chronic smokers compared to nonsmokers [26]. The release of other CXC chemokines, such as GRO- $\alpha$ and ENA-78, in addition to IL-8, from the alveolar macrophages of smokers is also enhanced [27]. Acute exposure to cigarette smoke also leads to release of these CXC chemokines. Thus, the initiation of cytokine release in COPD is likely to be due to the direct effect of cigarette smoking, although, in general, the release of cytokines in COPD patients is higher than that in asymptomatic smokers. Cigarette smoke increases IL-8 gene expression and release by bronchial epithelial cells, and TNF- $\alpha$ and IL- 6 by alveolar macrophages $[28,29]$, and oxidants that are present in cigarette smoke cause the release of proinflammatory cytokines such as IL-1 and IL-8 from macrophages and epithelial cells. Exposure of lung epithelial cells to smoke extract causes the release of neutrophilic and monocytic chemotactic activities, with IL-8 and G-CSF accounting for the neutrophilic activity and MCP-1 for the monocytic activity [30]. Acute exposure to cigarette smoke initiates a superoxidedependent mechanisms through expression of the transcription factor, nuclear factor- $\kappa \mathrm{B}$, which results in infiltration of neutrophils into the airways [31].

Elevated expression of MCP-1, TGF- $\beta 1$ and IL-8 and their mRNA has been observed in bronchiolar epithelium, and of CCR2 in macrophages from smokers with COPD compared with those without COPD [32]. Since MCP-1 binds to CCR2 and MCP-1 can induce $\mathrm{T}$-cell and monocytic migration, this chemokine of the CXC class [33], may contribute to the recruitment of these cells in COPD. It is not known which cytokines are involved in the recruitment of CD8+ T-cells to the airways of COPD patients. In the absence of IL-5 expression in COPD airways with eosinophilia, other eosinophil chemoattractants such as eotaxin or RANTES may be implicated. Alternatively, IL-5 may be produced by CD8+ T-cells, particularly the Tc2 subset, which are present in abundance in tissues of COPD.

Overexpression of the Th2-derived cytokine, IL-13, in lungs of adult mice induces emphysema, mucus goblet cell hyperplasia and airway inflammation with macrophages, lymphocytes and eosinophils, and increased MMP levels which are many of the features associated with COPD [34]. IL-13 is also overexpressed in an allergen-exposed sensitized mouse model, contributing to the eosinophilia, mucus hypersecretion and bronchial hyperresponsiveness in this asthma model [35]. However, it is not known whether this Th2-derived cytokine is overexpressed in COPD.

\section{Exacerbations of chronic obstructive pulmonary disease}

In acute exacerbations of COPD, eosinophils are prominent among the cells recovered from sputum or bronchial biopsy samples, but there is no increased expression of IL-5 in tissues [36]. Higher levels of IL-6 
and IL-8 in induced sputum from patients with increased number of exacerbations of COPD $(>3$ exacerbations $\left.\cdot \mathrm{yr}^{-1}\right)$, compared to those with $<2$ exacerbations $\cdot \mathrm{yr}^{-1}$, have been reported [37]. In a small group of patients with stable COPD (FEV1 of $76 \%$ of the predicted value), the number of lymphomononuclear cells expressing eotaxin mRNA was increased compared to healthy nonsmokers. In patients with an exacerbation of chronic bronchitis (FEV1 62\% pred), RANTES mRNA expression was upregulated and strong expression occurred in the surface epithelium and subepithelial lymphomononuclear cells; EG2+ esinophils were also increased [38]. The increased expression of CC chemokines, eotaxin and RANTES, may underlie the eosinophilia sometimes observed during exacerbations of COPD.

\section{Specific cytokines (tumour necrosis factor- $\alpha$, interleukin-1 $\beta$ and interleukin-8) in chronic obstructive pulmonary disease}

A summary profile of the cytokines potentially involved in COPD is shown in table 2, with further details of TNF- $\alpha$, IL- $1 \beta$ and IL- 8 provided below in this section.

\section{Tumour necrosis factor- $\alpha$}

TNF- $\alpha$ is produced by many cells including macrophages, T-cells, mast cells and epithelial cells, but the principal source is the macrophage. The secretion of TNF- $\alpha$ by monocytes/macrophages is greatly enhanced by other cytokines such as IL-1, GM-CSF and IFN- $\gamma$. A polymorphism in the promoter region of the TNF- $\alpha$ gene (position-308; TNF2 variant) leading to increased TNF- $\alpha$ production has been linked to COPD in a Taiwanese population [39], but this association has not been confirmed in other studies [40].

TNF- $\alpha$ activates the transcription factor, nuclear factor $-\kappa \mathrm{B}(\mathrm{NF}-\kappa \mathrm{B})$, that switches on transcription of the IL- 8 gene and increases IL- 8 release from the airway epithelium and neutrophils. Bacteria and bacterial products such as lipopolysaccharide can induce IL-8 expression, probably as a result of initial TNF- $\alpha$ production $[41,42]$. TNF- $\alpha$ increases expression of the adhesion molecule, ICAM-1, levels of which are increased in the serum of COPD patients [43]. TNF- $\alpha$ may activate macrophages to produce MMPs. This effect is inhibited by IL-10, which also enhances the release of tissue inhibitor of metalloproteinases (TIMP) in macrophages from normal volunteers, whereas IL-10 increases TIMP-1 release without modifying MMP-9 release in alveolar macrophages from smokers [25]. TNF- $\alpha$ also stimulates bronchial epithelial cells to produce tenascin, an extracellular matrix glycoprotein. Increased serum concentrations of TNF- $\alpha$ have been measured in patients with COPD with weight loss $[44,45]$, and this may be related to the effects of TNF- $\alpha$ on body mass and energy balance homeostasis, and in mediating acute phase responses.

\section{Interleukin-1 $\beta$}

IL-1 $\beta$ induces leukocytosis by the release of neutrophils from bone marrow, and also induces the release of many other cytokines such as IL-1, -2, -3, -4, $-5,-6$ and -8 , RANTES, GM-CSF, IFN- $\gamma$, TNF and PDGF from a variety of cells. It induces fibroblasts to proliferate, increases prostaglandin and collagenase secretion, and increases synthesis of fibronectin and collagen. Together with TNF- $\alpha$, IL-1 $\beta$ induces ICAM-1 expression on endothelial cells.

\section{Interleukin-8}

IL-8, a CXC chemokine, is a neutrophil chemoattractant and activator, which induces a transient shape change, a rise in intracellular calcium concentration, exocytosis with release of enzymes and proteins from intracellular storage organelles, and a respiratory burst. It also upregulates the expression of two integrins (CD11b/CD18 and CD11c/CD18) during the exocytosis of specific granules. IL-8 activates neutrophil 5-lipoxygenase with the formation of leukotriene $\mathrm{B}_{4}$ and 5-hydroxy-eicosanotetraenoic acid; leukotriene $\mathrm{B}_{4}$ may contribute to the chemotactic activity of sputum from COPD patients. IL-8 also has chemoattractant properties for T-cells. Bacteria can induce IL-8 expression in epithelial cells, and the increased levels of IL-8 found in sputum samples from COPD patients correlate with the airway bacterial load and myeloperoxidase released from activated neutrophils. Up to $43 \%$ of the chemotactic activity of sputum can be attributed to IL-8 [46]. Elastase released from neutrophils may also stimulate epithelial cells to produce more IL-8 [47] and leukotriene $\mathrm{B}_{4}[48]$.

\section{Airway wall remodelling cytokines}

Experimental approaches made possible by the availability of genetically modified mice have highlighted the potential role of various T-cell-derived cytokines in aspects of airway wall remodelling. Overexpression of these cytokines in airway epithelium causes various features of airway wall remodelling. A CC10-driven overexpression of IL-13 in lungs caused eosinophilic and mononuclear inflammation with goblet cell hyperplasia, subepithelial fibrosis, airway obstruction and airway hyperresponsiveness [49], which is more reminiscent of asthmatic inflammation. IL-4, -5 and -9 overexpression led to substantial mucus metaplasia, whereas IL-5 and -9 overexpression also caused subepithelial fibrosis and airways hyperresponsiveness [50-52] . Airway smooth muscle hyperplasia occurs following IL-11 overexpression [53]. Proliferation of myofibroblasts and hyperplasia of airway smooth muscle may also occur through the action of several growth factors such as PDGF and TGF- $\beta$. These may be released from inflammatory cells in the airways, such as macrophages and eosinophils, but also by structural cells such as airway epithelium, endothelial cells and 
Table 2. - Sources and effects of cytokines

\begin{tabular}{|c|c|c|}
\hline Cytokine & Sources & Important cellular and mediator effects \\
\hline \multicolumn{3}{|l|}{ Th2/Tc2 cytokines } \\
\hline \multirow[t]{5}{*}{ IL-4 } & Th2 & Increased eosinophil growth \\
\hline & Mast cells & Increased Th-2; decreased Th-1 \\
\hline & Basophils & Increased IgE \\
\hline & Eosinophils & Increased mucin expression and goblet cells \\
\hline & & Increased VCAM-1 expression on endothelial cells \\
\hline \multirow[t]{4}{*}{ IL-5 } & Th2 & Eosinophil maturation \\
\hline & Mast cells & Decreased apoptosis \\
\hline & Eosinophils & Increased $\mathrm{Th} 2$ \\
\hline & & BHR \\
\hline \multirow[t]{4}{*}{ IL-9 } & Th2 & Increased activated T-cells and IgE from B-cells \\
\hline & Eosinophils & Increased mast cell growth and differentiation \\
\hline & & Increased mucin expression and goblet cells \\
\hline & & Causes eosinophilic inflammation and BHR \\
\hline \multirow[t]{5}{*}{ IL-13 } & Th2 & Activates eosinophils \\
\hline & Basophils & Decreased apoptosis \\
\hline & Eosinophils & Increased $\mathrm{IgE}$ \\
\hline & Natural killer cells & Increased mucin expression and goblet cells \\
\hline & & Induces emphysema and matrix metalloproteinases \\
\hline \multicolumn{3}{|r|}{ 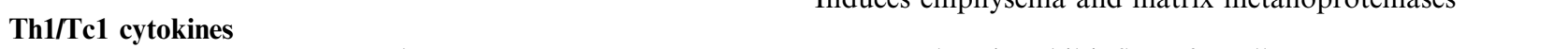 } \\
\hline \multirow[t]{5}{*}{ IFN- $\gamma$} & Th1 & Decreased eosinophil influx after allergen \\
\hline & Natural killer cells & Decreased $\mathrm{Th} 2$ \\
\hline & & $\begin{array}{l}\text { Activates endothelial cells, epithelial cells, } \\
\text { alveolar macrophages/monocytes }\end{array}$ \\
\hline & & Decreased IgE \\
\hline & & Decreased BHR \\
\hline \multirow[t]{3}{*}{ IL-2 } & Th0 and Th1 & Eosinophilia in vivo \\
\hline & Eosinophils & Growth and differentiation of T-cells \\
\hline & Airway epithelial cells & \\
\hline \multirow[t]{4}{*}{ IL-12 } & B-cells & Regulates Th1 differentiation \\
\hline & Monocytes/macrophages & Decreased expansion of Th2 \\
\hline & Dendritic cells & Decreased IL-4-induced IgE synthesis \\
\hline & Eosinophils & Stimulates natural killer cells and T-cells to produce IFN- $\gamma$ \\
\hline \multirow[t]{5}{*}{ IL-18 } & Th1 cells & Induces IFN- $\gamma$ release from mitogen-stimulated \\
\hline & Airway epithelium & blood mononuclear cells \\
\hline & & Induces Th1 development together with IL-12 \\
\hline & & Causes release of IL- 8, MIP1- $1 \alpha$ and \\
\hline & & MCP-1 from mononuclear cells \\
\hline \multirow{8}{*}{$\begin{array}{l}\text { Proinflammatory } \\
\text { IL-1 }\end{array}$} & & \\
\hline & $\begin{array}{l}\text { Monocytes/macrophages } \\
\text { Fibroblasts }\end{array}$ & $\begin{array}{l}\text { Increased adhesion to vascular endothelium; } \\
\text { eosinophil accumulation in vivo }\end{array}$ \\
\hline & B-cells & Growth factor for Th2 \\
\hline & Th1 and Th2 & B-cell growth factor; neutrophil chemoattractant; \\
\hline & Neutrophils & T-cell and epithelial activation \\
\hline & Endothelial cells & BHR \\
\hline & Airway epithelial cells & \\
\hline & Airway SMCs & \\
\hline \multirow[t]{6}{*}{ TNF- $\alpha$} & Macrophages & Activates epithelium, endothelium, \\
\hline & T-cells & antigen-presenting-cells, monocyt \\
\hline & Mast cells & monocytes/macrophages \\
\hline & Airway epithelial cells & BHR \\
\hline & & Increased IL-8 from epithelial cells \\
\hline & & Increased matrix metalloproteinases from macrophages \\
\hline \multirow[t]{5}{*}{ IL-6 } & Monocytes/macrophages & T-cell growth factor \\
\hline & T-cells & B-cell growth factor \\
\hline & B-cells & Increased IgE \\
\hline & Fibroblasts & \\
\hline & Airway epithelial cells & \\
\hline \multirow[t]{4}{*}{ IL-8 } & Monocytes/macrophages & Neutrophil chemoattractant and activator \\
\hline & Airway epithelial cells & Chemotactic for CD8+ T-cells \\
\hline & Airway SMCs & Activates 5-lipoxygenase in neutrophils \\
\hline & Eosinophils & $\begin{array}{l}\text { Induces release of histamine and cys-being } \\
\text { leukotrienes from basophils }\end{array}$ \\
\hline
\end{tabular}


Table 2. - Cont.

\begin{tabular}{|c|c|c|}
\hline Cytokine & Sources & Important cellular and mediator effects \\
\hline IL-11 & $\begin{array}{l}\text { Airway epithelial cells } \\
\text { Airway SMCs } \\
\text { Fibroblasts } \\
\text { Eosinophils }\end{array}$ & $\begin{array}{l}\text { B-cell growth factor } \\
\text { Activates fibroblasts } \\
\text { BHR }\end{array}$ \\
\hline IL-16 & $\begin{array}{l}\text { CD8+ T-cells } \\
\text { Epithelial cells } \\
\text { Eosinophils } \\
\text { Mast cells }\end{array}$ & $\begin{array}{l}\text { Eosinophil migration } \\
\text { Growth factor and chemotaxis of CD4+ T-cells }\end{array}$ \\
\hline IL-17 & CD4+ T-cells & $\begin{array}{l}\text { T-cell proliferation } \\
\text { Activates epithelia, endothelial cells, fibroblasts } \\
\text { Induces release of IL-6, IL-8 and GM-CSF } \\
\text { Neutrophil chemoattractant and activator }\end{array}$ \\
\hline GM-CSF & $\begin{array}{l}\text { T-cells } \\
\text { Macrophages } \\
\text { Eosinophils } \\
\text { Fibroblasts } \\
\text { Endothelial cells } \\
\text { Airway SMCs } \\
\text { Airway epithelial cells }\end{array}$ & $\begin{array}{l}\text { Eosinophil apoptosis and activation; } \\
\quad \text { induces release of leukotrienes } \\
\text { Proliferation and maturation of haematopoietic cells } \\
\text { Endothelial cell migration } \\
\text { BHR }\end{array}$ \\
\hline Inhibitory cytokines & & \\
\hline IL-10 & $\begin{array}{l}\text { Th2 } \\
\text { CD8+ T-cells } \\
\text { Monocytes/macrophages }\end{array}$ & $\begin{array}{l}\text { Decreased eosinophil survival } \\
\text { Decreased Th1 and Th2 } \\
\text { Decreased monocyte/macrophage activation; } \\
\uparrow \text { B-cell; } \uparrow \text { mast cell growth } \\
\text { Decreased BHR }\end{array}$ \\
\hline IL-1RA & Monocytes/macrophages & $\begin{array}{l}\text { Decreased Th2 proliferation } \\
\text { Decreased BHR }\end{array}$ \\
\hline IL-18 & $\begin{array}{l}\text { Dendritic cells } \\
\text { Monocytes } \\
\text { Natural killer cells }\end{array}$ & $\begin{array}{l}\text { Enhances Th1 via IFN- } \gamma \text { release } \\
\text { Releases IFN- } \gamma \text { from Th1 } \\
\text { Activates natural killer cells, monocytes } \\
\text { Decreased IgE }\end{array}$ \\
\hline $\begin{array}{l}\text { Growth factors } \\
\text { PDGF }\end{array}$ & $\begin{array}{l}\text { Macrophages } \\
\text { Airway epithelium } \\
\text { Fibroblasts }\end{array}$ & $\begin{array}{l}\text { Fibroblast and airway smooth muscle proliferation } \\
\text { Release of collagen }\end{array}$ \\
\hline TGF- $\beta$ & $\begin{array}{l}\text { Macrophages } \\
\text { Eosinophils } \\
\text { Airway epithelium }\end{array}$ & $\begin{array}{l}\text { Decreased T-cell proliferation } \\
\text { Blocks IL-2 effects } \\
\text { Fibroblast proliferation } \\
\text { Chemoattractant for monocytes, fibroblasts, mast cells } \\
\text { Decreased airway smooth muscle proliferation }\end{array}$ \\
\hline
\end{tabular}

Th: T-helper cell; Tc: cytotoxic T-cell; IL: interleukin; IgE: immunoglobulin E; BHR: bronchial hyperresponsiveness; IFN- $\gamma$ : interferon gamma; MIP-1 $\alpha$ : macrophage inflammatory factor $1 \alpha$; MCP-1: monocyte chemotactic protein-1; SMC: smooth muscle cell; TNF- $\alpha$ : tumour necrosis factor- $\alpha$; GM-CSF: granulocyte-macrophage colony-stimulating factor; IL-1RA: IL-1 receptor antagonist; PDGF: platelet-derived growth factor; TGF- $\beta$ : transforming growth factor- $\beta$; VCAM: vascular adhesion molecule.

fibroblasts. These growth factors may stimulate fibrogenesis by recruiting and activating fibroblasts or by transforming myofibroblasts. TGF- $\beta$ is capable of inducing the production of TIMPs [54]. Epithelial cells may release growth factors since collagen deposition occurs underneath the basement membrane of the airway epithelium [55]. In addition, increased release of TGF- $\beta$ and fibronectin from alveolar macrophages from patients with chronic bronchitis has been observed [56]. Growth factors may also stimulate the proliferation and growth of airway smooth muscle cells. PDGF and EGF are potent stimulants of human airway smooth muscle proliferation [57], and these effects are mediated via activation of tyrosine kinase and protein kinase C. Airway smooth muscle cells have the capacity to elaborate a range of cytokines including IL-4, IL-5, GM-CSF, IL-8, eotaxin and
MCP-1, and therefore may play a role in the induction of local inflammatory responses [58]. Cytokines, such as TNF- $\alpha$ and fibroblast growth factors, may also play an important role in angiogenesis.

An increase in the expression of TGF- $\beta$ and also of EGF in the epithelium and submucosal cells of patients with chronic bronchitis has been reported [59]. Expression of TGF- $\beta 1$ and its mRNA in ithe bronchiolar and alveolar epithelium of COPD patients is increased and correlates with the number of intraepithelial macrophages [60]. Tobacco smoke directly activates transcription of the mucin MUC5AC through an EGF receptor kinasedependent pathway. EGF is of interest since EGF receptor activation by $\mathrm{TNF}-\alpha$ leads to the expression of mucin genes, in particular MUC5A [61]. These growth factors may be implicated in repair responses 
following injury, particularly to the epithelium. Growth factors such as TGF- $\beta$ and EGF may be involved in fibroblast activation and proliferation leading to peribronchiolar fibrosis.

\section{Differences between chronic obstructive pulmonary disease and asthma}

Although the complex role of cytokines has not been fully dissected, it appears that the profile of cytokine expression in COPD is different from that in asthma (table 3 ). This may be expected, to a large extent, from the different pathologies observed in the two diseases, particularly at the level of the cellular infiltrate. Thus, in asthma, an infiltration of eosinophils and CD4+ T-cells, rather than of neutrophils and CD8+ T-cells is usually found. In support of this, the cytokine expression important to asthma is Th2derived, involving cytokines such as IL-4, -5 and -13 $[62,63]$, whereas in COPD, the neutrophil chemokine IL- 8 and proinflammatory cytokines IL- 1 and TNF- $\alpha$ play a more prominent role. However, there are overlaps between the two disease processes, such as the eosinophilic inflammation that occurs in some COPD patients [21] and the increased neutrophilic expression occurring in some patients with more severe asthma [64, 65]. In this regard, no increase in IL-5 expression in COPD has been detected in the bronchial mucosa. However, a recent biopsy study of patients with stable chronic bronchitis found increased numbers of mononuclear cells staining for eotaxin mRNA, whereas, in patients with exacerbations, an increase in RANTES mRNA expression was found in the epithelium and in mononuclear cells [38]. This may indicate that eotaxin and RANTES

Table 3. - Expression ${ }^{+}$of cytokines in asthma and chronic obstructive pulmonary disease (COPD)

\begin{tabular}{lcc}
\hline & Asthma & COPD \\
\hline IL-3 & + & $?$ \\
IL-4 & ++ & \pm \\
IL-5 & ++ & \pm \\
IL-10 & + or & $?$ \\
IL-13 & + & $?$ \\
Eotaxin & ++ & ++ \\
RANTES & \pm & $++^{*}$ \\
MCP-1 & $?$ & + \\
IL-8 & \pm & ++ \\
IL-1 $\beta$ & $?$ & + \\
TNF- $\alpha$ & + & + \\
TGF- $\beta$ & + & + \\
EGF & \pm & + \\
\hline
\end{tabular}

+. usually reported as gene or protein in airway tissues, in addition to measurement of protein release in airway fluids; *: during exacerbation; -: recuced; + : small increase; ++ : large increase; ?: not known or uncertain; \pm : no change or negligible. IL: interleukin; RANTES: regulated on activation, normal T-cell expressed and secreted; MCP-1: monocyte chemotactic protein-1; TNF- $\alpha$ : tumour necrosis factor- $\alpha$; TGF- $\beta$ : transforming growth factor- $\beta$; EGF: epidermal growth factor. contribute to the eosinophilic and lymphocytic inflammation in asthma.

The mechanism by which cytokines may be induced is of interest. The role of transcription factors has been studied to a limited extent. There has been interest in the transcription factor $\mathrm{NF}-\kappa \mathrm{B}$, which may be important for the generation of IL-8 on exposure to cigarette smoke. Oxidative stress may also lead to the activation of $\mathrm{NF}-\kappa \mathrm{B}$ [66]. In asthma, there is increased expression of many proteins, such as RANTES and inducible nitric oxide synthase, in the airway epithelium $[67,68]$. In addition, expression of $\mathrm{NF}-\kappa \mathrm{B}$ is increased in the airway epithelium and alveolar macrophages of subjects with asthma [69], which may underlie this increase in expression of RANTES and inducible nitric oxide synthase. However, in COPD, NF- $\kappa \mathrm{B}$ expression or deoxyribonucleic acid-binding activity is unexpectedly not increased [69], indicating that $\mathrm{NF}-\kappa \mathrm{B}$ may not be required for the transcription of cytokines such as IL-8 in COPD. There may be important differences between asthma and COPD at the level of transcriptional control of inflammatory cytokines. The difference in expression of $\mathrm{NF}-\kappa \mathrm{B}$ between asthma and COPD is unclear.

More studies are needed for the direct comparison of asthma and chronic obstructive pulmonary disease, and also to focus on patients who manifest clinical features of both chronic obstructive pulmonary disease and asthma. Further analysis of cytokine expression in asthma and chronic obstructive pulmonary disease may help determine whether these conditions have common mechanisms or similar predisposing factors. In addition, it may reveal some common pathways in the two conditions.

\section{References}

1. Mossman TR, Coffman RL. TH1 and TH2 cells: different patterns of lymphokine secretion lead to different functional properties. Аnпи Rev Immunol 1989; 7: 145-173.

2. Hamid Q, Azzawi M, Sun Ying, et al. Expression of mRNA for interleukin-5 in mucosal bronchial biopsies from asthma. J Clin Invest 1991; 87: 1541-1549.

3. Robinson DS, Hamid Q, Ying S, et al. Predominant Th2-type bronchoalveolar lavage T-lymphocyte population in atopic asthma. New Engl J Med 1992; 326: 298-304.

4. Salgame P, Abrams JS, Clayberger C, et al. Differing lymphokine profile of functional subsets of human CD4 and CD8 T cell clones. Science 1991; 254: 279-282.

5. Salgame P, Convit J, Bloom BR. Immunological suppression by human CD8+ $\mathrm{T}$ cells is receptor dependent and HLA-DQ restricted. Proc Natl Acad Sci USA 1991; 88: 2598-2602.

6. Sad S, Mosmann TR. Interleukin (IL) 4, in the absence of antigen stimulation, induces an anergy-like state in differentiated CD8+ TC1 cells: loss of IL-2 synthesis and autonomous proliferation but retention of cytotoxicity and synthesis of other cytokines. $J$ Exp Med 1995; 182: 1505-1515.

7. Croft M, Carter L, Swain SL, Dutton RW. Generationof polarized antigen-specific CD8 effector 
populations: reciprocal action of interleukin (IL)-4 and IL-12 in promoting type 2 versus type 1 cytokine profiles. J Exp Med 1994; 180: 1715-1728.

8. Saetta M, Di SA, Turato G, et al. CD8+ Tlymphocytes in peripheral airways of smokers with chronic obstructive pulmonary disease. Am J Respir Crit Care Med 1998; 157: 822-826.

9. Carter LL, Dutton RW. Relative perforin- and Fasmediated lysis in T1 and T2 CD8 effector populations. J Immunol 1995; 155: 1028-1031.

10. Coyle AJ, Erard F, Bertrand C, Walti S, Pircher H, Le Gros G. Virus-specific CD8+ cells can switch to interleukin 5 production and induce airway eosinophilia. J Exp Med 1995; 181: 1229-1233.

11. Yoshimura $\mathrm{T}$, Matsushima K, Oppenheim JJ, Leonard EJ. Neutrophil chemotactic factor produced by lipopolysaccharide (LPS)-stimulated human blood mononuclear leukocytes: partial characterization and separation from interleukin 1 (IL 1). J Immunol 1987; 139: 788-793

12. Walz A, Peveri $\mathrm{P}$, Aschauer $\mathrm{H}$, Baggiolini $\mathrm{M}$. Purification and amino acid sequencing of NAF, a novel neutrophil- activating factor produced by monocytes. Biochem Biophys Res Commun 1987; 149: 755-761.

13. Luster AD. Chemokines - chemotactic cytokines that mediate inflammation. $N$ Engl J Med 1998; 338: 436445.

14. Kelner GS, Kennedy J, Bacon KB, et al. Lymphotactin: a cytokine that represents a new class of chemokine. Science 1994; 266: 1395-1399.

15. Lord BI, Bronchud MH, Owens S, et al. The kinetics of human granulopoiesis following treatment with granulocyte colony-stimulating factor in vivo. Proc Natl Acad Sci USA 1989; 86: 9499-9503.

16. de Haas M, Kerst JM, van der Schoot CE, et al. Granulocyte colony-stimulating factor administration to healthy volunteers: analysis of the immediate activating effects on circulating neutrophils. Blood 1994; 84: 3885-3894.

17. Khwaja A, Carver JE, Linch DC. Interactions of granulocyte-macrophage colony-stimulating factor (CSF), granulocyte CSF, and tumor necrosis factor$\alpha$ in the priming of the neutrophil respiratory burst. Blood 1992; 79: 745-753.

18. Betsuyaku T, Liu F, Senior RM, et al. A functional granulocyte colony-stimulating factor receptor is required for normal chemoattractant-induced neutrophil activation. J Clin Invest 1999; 103: 825-832.

19. Hallsworth MP, Litchfield TM, Lee TH. Glucocorticosteroids inhibit granulocyte-macrophage colonystimulating factor and interleukin-5 enhanced in vitro survival of human eosinophils. Immunology 1992; 75: 382-385.

20. Jeffery PK. Structural and inflammatory changes in COPD: a comparison with asthma. Thorax 1998; 53: 129-136.

21. Chanez $\mathrm{P}$, Vignola $\mathrm{AM}, \mathrm{O}^{\prime}$ Shaugnessy $\mathrm{T}$, et al. Corticosteroid reversibility in COPD is related to features of asthma. Am J Respir Crit Care Med 1997; 155: $1529-1534$.

22. Shapiro SD. The macrophage in chronic obstructive pulmonary disease. Am J Respir Crit Care Med 1999; 160: S29-S32.

23. Finlay GA, $\mathrm{O}^{\prime}$ Driscoll LR, Russell KJ, et al. Matrix metalloproteinase expression and production by alveolar macrophages in emphysema [see comments]. Am J Respir Crit Care Med 1997; 156: 240-247.

24. Keatings VM, Collins PD, Scott DM, Barnes PJ. Differences in interleukin-8 and tumor necrosis factor- $\alpha$ in induced sputum from patients with chronic obstructive pulmonary disease or asthma. Am J Resp Crit Care Med 1996; 153: 530-534.

25. Lim S, Roche N, Oliver BG, Mattos W, Barnes PJ, Chung KF. Balance of matrix metalloprotease-9 and tissue inhibitor of metalloprotease-1 from alveolar macrophages in cigarette smokers: regulation by interleukin-10. Am J Respir Crit Care Med 2000; 162: $1355-1360$.

26. Kuschner WG, D'Alessandro A, Wong H, Blanc PD. Dose-dependent cigarette smoking-related inflammatory responses in healthy adults. Eur Respir J 1996; 9: 1989-1994.

27. Morrison D, Strieter RM, Donnelly SC, Burdick MD, Kunkel SL, MacNee W. Neutrophil chemokines in bronchoalveolar lavage fluid and leukocyteconditioned medium from nonsmokers and smokers. Eur Respir J 1998; 12: 1067-1072.

28. Mio T, Romberger DJ, Thompson AB, Robbins RA, Heires A, Rennard SI. Cigarette smoke induces interleukin-8 release from human bronchial epithelial cells. Am J Respir Crit Care Med 1997; 155: 1770-1776.

29. Dubar V, Gosset P, Aerts C, Voisin C, Wallaert B, Tonnel AB. In vitro acute effects of tobacco smoke on tumor necrosis factor- $\alpha$ and interleukin- 6 production by alveolar macrophages. Exp Lung Res 1993; 19: 345-359.

30. Masubuchi T, Koyama S, Sato E, et al. Smoke extract stimulates lung epithelial cells to release neutrophil and monocyte chemotactic activity. Am J Pathol 1998; 153: 1903-1912.

31. Nishikawa M, Kakemizu N, Ito T, et al. Superoxide mediates cigarette smoke-induced infiltration of neutrophils into the airways through nuclear factor- $\kappa \mathrm{B}$ activation and IL-8 mRNA expression in guinea pigs in vivo. Am J Respir Cell Mol Biol 1999; 20: 189-198.

32. de Boer W, Sont JK, van SA, Stolk J, van KJ, Hiemstra PS. Monocyte chemoattractant protein 1, interleukin 8 , and chronic airways inflammation in COPD. J Pathol 2000; 190: 619-626.

33. Premack BA, Schall TJ. Chemokine receptors: gateways to inflammation and infection. Nat Med 1996; 2: 1174-1178.

34. Zheng T, Zhu Z, Wang Z, et al. Inducible targeting of IL13 to the adult lung causes matrix metalloproteinaseand cathepsin-dependent emphysema. J Clin Invest 2000; 106: 1081-1093.

35. Wills-Karp M, Luyimbazi J, Xu X, et al. Interleukin13: central mediator of allergic asthma. Science 1998; 282: 2258-2261.

36. Saetta M, Di SA, Maestrelli P, et al. Airway eosinophilia and expression of interleukin-5 protein in asthma and in exacerbations of chronic bronchitis [see comments]. Clin Exp Allergy 1996; 26: 766-774.

37. Wedzicha JA, Seemungal TA, MacCallum PK, et al. Acute exacerbations of chronic obstructive pulmonary disease are accompanied by elevations of plasma fibrinogen and serum IL-6 levels [In Process Citation]. Thromb Haemost 2000; 84: 210-215.

38. Zhu J, Qiu YS, Majumdar S, et al. Exacerbations of bronchitis: bronchial eosinophilia and gene expression for IL4, IL5, and eosinophil chemoattractants. Am $J$ Respir Crit Care Med 2001; In press. 
39. Huang SL, Su CH, Chang SC. Tumor necrosis factor- $\alpha$ gene polymorphism in chronic bronchitis. Am J Respir Crit Care Med 1997; 156: 1436-1439.

40. Higham MA, Pride NB, Alikhan A, Morrell NW. Tumour necrosis factor- $\alpha$ gene promoter polymorphism in chronic obstructive pulmonary disease. Eur Respir J 2000; 15: 281-284.

41. Khair OA, Devalia JL, Abdelaziz MM, Sapsford RJ, Tarraf H, Davies RJ. Effect of Haemophilus influenzae endotoxin on the synthesis of IL-6, IL-8, TNF- $\alpha$ and expression of ICAM-1 in cultured human bronchial epithelial cells. Eur Respir J 1994; 7: 2109-2116.

42. Inoue H, Massion PP, Ueki IF, et al. Pseudomonas stimulates interleukin-8 mRNA expression selectively in airway epithelium, in gland ducts, and in recruited neutrophils. Am J Respir Cell Mol Biol 1994; 11: 651-663.

43. Riise GC, Larsson S, Lofdahl CG, Andersson BA. Circulating cell adhesion molecules in bronchial lavage and serum in COPD patients with chronic bronchitis. Eur Respir J 1994; 7: 1673-1677.

44. Di FM, Barbier D, Mege JL, Orehek J. Tumor necrosis factor-alpha levels and weight loss in chronic obstructive pulmonary disease. Am J Respir Crit Care Med 1994; 150: 1453-1455.

45. Schols AM, Buurman WA, Staal van den Brekel AJ, Dentener MA, Wouters EF. Evidence for a relation between metabolic derangements and increased levels of inflammatory mediators in a subgroup of patients with chronic obstructive pulmonary disease. Thorax 1996; 51: 819-824.

46. Mikami M, Llewellyn-Jones CG, Bayley D, Hill SL, Stockley RA. The chemotactic activity of sputum from patients with bronchiectasis. Am J Respir Crit Care Med 1998; 157: 723-728.

47. Nakamura H, Yoshimura K, McElvaney NG, Crystal RG. Neutrophil elastase in respiratory epithelial lining fluid of individuals with cystic fibrosis induces interleukin- 8 gene expression in a human bronchial epithelial cell line. J Clin Invest 1992; 89: 1478-1484.

48. McCain RW, Holden EP, Blackwell TR, Christman $\mathrm{JW}$. Leukotriene $\mathrm{B}_{4}$ stimulates human polymorphonuclear leukocytes to synthesize and release interleukin8 in vitro. Am J Respir Cell Mol Biol 1994; 10: 651-657.

49. Zhu Z, Homer RJ, Wang Z, et al. Pulmonary expression of interleukin-13 causes inflammation, mucus hypersecretion, subepithelial fibrosis, physiologic abnormalities, and eotaxin production. J Clin Invest 1999; 103: 779-788.

50. Temann UA, Geba GP, Rankin JA, Flavell RA. Expression of interleukin 9 in the lungs of transgenic mice causes airway inflammation, mast cell hyperplasia, and bronchial hyperresponsiveness. J Exp Med 1998; 188: 1307-1320.

51. Rankin JA, Picarella DE, Geba GP, et al. Phenotypic and physiologic characterization of transgenic mice expressing interleukin 4 in the lung: lymphocytic and eosinophilic inflammation without airway hyperreactivity. Proc Natl Acad Sci USA 1996; 93: 7821-7825.

52. Lee JJ, McGarry MP, Farmer SC, et al. Interleukin-5 expression in the lung epithelium of transgenic mice leads to pulmonary changes pathognomonic of asthma. J Exp Med 1997; 185: 2143-2156.

53. Einarsson O, Geba GP, Zhu Z, Landry M, Elias JA. Interleukin-11: stimulation in vivo and in vitro by respiratory viruses and induction of airways hyperresponsiveness. J Clin Invest 1996; 97: 915-924.
54. Border WA, Noble NA. Transforming growth factor$\beta$ in tissue fibrosis. $N$ Engl $\mathrm{J} \mathrm{Med} \mathrm{1994;} \mathrm{331:} \mathrm{1286-}$ 1292.

55. Brewster CEP, Howarth PH, Djukanovic R, Wilson J, Holgate ST, Roche WR. Myofibroblasts and subepithelial fibrosis in bronchial asthma. Am J Respir Cell Mol Biol 1990; 3: 507-511.

56. Vignola AM, Chanez P, Chiappara G, et al. Release of transforming growth factor- $\beta$ (TGF- $\beta$ ) and fibronectin by alveolar macrophages in airway diseases. Clin Exp Immunol 1996; 106: 114-119.

57. Hirst SJ, Barnes PJ, Twort CHL. Quantifying proliferation of cultured human and rabbit airway smooth muscle cells in response to serum and plateletderived growth factor. Am J Respir Cell Mol Biol 1992; 7: 574-581.

58. Chung KF. Airway smooth muscle cells: contributing to and regulating airway mucosal inflammation? Eur Respir J 2000; 15: 961-968.

59. Vignola AM, Chanez P, Chiappara G, et al. Transforming growth factor- $\beta$ expression in mucosal biopsies in asthma and chronic bronchitis. $\mathrm{Am}$ J Respir Crit Care Med 1997; 156: 591-599.

60. de Boer W, van Shadwicke A, Sont JK, et al. Transforming growth factor $\beta 1$ and recruitment of macrophages and mast cells in airways in chronic obstructive pulmonary disease. Am J Respir Crit Care Med 1998; 158: 1951-1957.

61. Takeyama K, Dabbagh K, Lee HM, et al. Epidermal growth factor system regulates mucin production in airways. Proc Natl Acad Sci USA 1999; 96: 3081-3086.

62. Hamid Q, Azzawi M, Sun Ying, et al. Expression of mRNA for interleukin-5 in mucosal bronchial biopsies from asthma. J Clin Invest 1991; 87: 1541-1549.

63. Humbert $\mathrm{M}$, Ying S, Corrigan $\mathrm{C}$, et al. Bronchial mucosal expression of the genes encoding chemokines RANTES and MCP-3 in symptomatic atopic and nonatopic asthmatics: relationship to the eosinophil-active cytokines interleukin (IL)-5, granulocyte macrophage-colony-stimulating factor, and IL-3. Am J Respir Cell Mol Biol 1997; 16: 1-8.

64. Jatakanon A, Uasuf C, Maziak W, Lim S, Chung KF, Barnes PJ. Neutrophilic inflammation in severe persistent asthma. Am J Respir Crit Care Med 1999; 160: 1532-1539.

65. Wenzel SE, Szefler SJ, Leung DYM, Sloan SI, Rex MD, Martin RJ. Bronchoscopic evaluation of severe asthma: persistent inflammation associated with high dose glucocorticoids. Am J Respir Crit Care Med 1997; 156: 737-743.

66. Haddad E-B, Salmon M, Koto H, Barnes PJ, Adcock I, Chung KF. Ozone induction of cytokine-induced neutrophil chemoattractant (CINC) and nuclear factor- $\kappa \mathrm{B}$ in rat lung: inhibition by corticosteroids. FEBS Lett 1996; 379: 265-268.

67. Berkman N, Krishnan VL, Gilbey T, et al. Expression of RANTES mRNA and protein in airways of patients with mild asthma. Am J Resp Crit Care Med 1996; 154: 1804-1811.

68. Springall DR, Hamid QA, Buttery LKD, et al. Nitric oxide synthase induction in asthmatic human lung. Am Rev Respir Dis 1993; 147: 1510-1513.

69. Hart LA, Krishnan VL, Adcock IM, Barnes PJ, Chung KF. Activation and localisation of transcription factor, nuclear factor- $\kappa \mathrm{B}$, in asthma. Am J Respir Crit Care Med 1998; 158: 1585-1592. 